\title{
Recharacterization of Gymnodamaeoidea and erection of Plateremaeoidea (Acari, Oribatei), with key to families and genera.
}

\author{
Adilson D. Paschoal ${ }^{1}$
}

\begin{abstract}
The present paper deals with the recharacterization of the Gymnodamaeoidea and the erection of Plateremaeoidea n. grad. (Acari, Oribatei). Gymnodamaeidae Grandjean, Aleurodamaeidae Paschoal \&Johnston, and Idiodamaeidae Paschoal are recognised under the Gymnodamaeoidea. Plateremaeidae Tragardh, Pheroliodidae Paschoal, Nooliodidae Paschoal, Hammeriellidae Paschoal, Lyrifissellidae Paschoal, Pedrocortesellidae Paschoal, Licnodamaeidae Grandjean and Licnobelbidae Grandjean are included in Plateremaeoidea. A key to the families and genera of Gymnodamaeoidea and Plateremaeoidea is also provided.
\end{abstract}

Gymnodamaeoidea was proposed by Grandjean for the families Gymnodamaeidae Grandjean, Licnobelbidae Grandjean, Licnodamaeidae Grandjean and Plateremaeidae Tragardh, all having in common the absence of trachea I and its stigma (tracheal system sub-normal, with only tracheae III and sejugal), and the reduction in number of the notogastral setae, the centro-dorsals always absent. Close families as Liodidae, Hermanniellidae and Plasmobatidae have abnormal tracheal system.

A new dimension to the Gymnodamaeoidea was given by Balogh (1972), who placed it in the group Polytricha (with more than six pairs of genital setae), together with Liodoidea, Hermannielloidea, Hermannoidea and Nanhermannoidea, according to him, could be distinguished by the following characteristics: notogastral setae reduced in number, being restricted to the posteromarginal pairs (three to six pairs on adults); notogaster flat or excavated, occasionally with exuviae or cerotegument; ro, le originated one close to the other; legs very long and filiform or on sockets; anal setae varying from three to six pairs. He admited as Gymnodamaeoidea the same families pointed out by Grandjean (1965).

In the present paper a completely new statement is givento the Gymnodamaeoidea with the erection of Plateremaeoidea. The conclusions were drawn from two basic dissertation works presented by Paschoal $(1975,1979)$. split into several published papers (See the References). 


\section{Superfamily Gymnodamaeoidea Grandjean}

Gymnodamaeoidea Grandjean, 1954; Grandjean, 1965; Balogh, 1972; Paschoal, 1979.

Characteristics - Eupheredermes, i. e., nymphs retain exuviae of previous instars; adults with or without exuviae. Tracheal system sub-normal, i. e., trachea I missing; only tracheae III and sejugal present. Pycnonotics, i. e., without areae porosae on notogaster. Body and legs covered by cerotegument with or without microtubercles. Cuticle smooth, with no foveae nor reticula. Prodorsal apodemata generally present. le dorsal to dorso-lateral, anterior or posterior to ro; ro ventral; ex lateral, short; in minute, anterior to or between bothridia; bothridium dorsal; ss clavate or flagellate, with distal spinules generally. Notogastral dorsocentral setae absent on adults; with six pairs of posterolateral notogastral setae (ps1, ps2, ps3, h1, r2, r3), or five pairs (r3 absent), or fours pairs (r3, r2 absent), or three pairs (r3, r2, ps3 absent). With three pairs of dorsal lyrifissures (ia, im, ip) and two pairs of lateral lyrifissures (ips, ih). Notogaster ovate or circular, flat to slightly convex. Notogastral tectum present between bng and lambda lines. Apo I complete; all other epimeral apodemata incomplete, with or without transversal apodematic bonds. Epimeral chaetotaxy $3: 1: 3: 3$ (normal), or $2: 2: 3: 3$ (la on ep II), or $2: 2: 4: 2$ (la on ep II, 4a on ep IV); epimeral setae of equal size. Genital aperture square to almost circular; anal aperture pyriform; genital and anal apertures contiguous, joint or not joint. Genitoanal chaetotaxy 7 (or 6) - $1-3$ (or 2) - 3 (or 2); genital setae on a sole longitudinal row generally; ag lateral or posterior to genitalia. Pedotecta I, II present, auriculiform; pedotectal tooth $\mathbf{p}$ absent; lateral carenae present; acetabula I, II integument and cotyloid forming a pointed structure. Leg articulations not on proximal sockets or on sockets only at the adult stage; $\mathrm{Tr}$ and $\mathrm{Fe}$ - Tr articulations of legs I, II inside acetabula; femora proximal portion after trochantera articulation sinuous; femoral and trochanteral tracheae absent; with three small claws, the medial one the strongest; tarsi fusiform with no true pedicels; famulus enclosed in Ts I; p Ts I tactile; omega 1 Ts I paraxial, larger than omega 2, close to it, not on distal apophysis; Tb I apophysis short, with two solenidia and a tactile seta; fil Tb I long, antiaxial, associated with a tactile seta; fi2 Tb I paraxial, short; femora bulbous; Ts II with two equally developed solenidia, or with just one long solenidium; ft' Ts III, IV present or absent; (it) Ts IV absent; pl' Ts II, IV absent. Leg chaetotaxy: Ts. 19(2) - 16(2) or 16(1)16 or $15-13$ or 12 ; Tb. 5 (2) - 5 (1) - 4 (1) $-4(1)$; Ge. 4 (1) or $3(1)-$ $4(1)-3(1)-3$; Fe. $5-5-3-2$ or 3 ; Tr. $1-1-2-1$.

Recongnised families: Gymnodamaeidae Grandjean, (Paschoal, 1975, $1982 \mathbf{a}$ - c, 1983a - b, 1984a - f; Paschoal \& Johnston, 1982a, b); Aleurodamaeidae Paschoal \& Johnston, (Paschoal, 1975; Paschoal \& Johnston, 1984); and Idiodamaeidae Paschoal, (Paschoal, 1979; Paschoal, 1984f, 1987d). 
Superfamily Plateremaeoidea Tragardh n. grad.

Characteristics - Eupheredermes - i. e., nymphs retain exuviae or preceding instars; adults with or without exuviae. Tracheal system sub-normal, i.e., trachea I missing, only the tracheae III and sejugal present. Pycnonotics, i. e., without - areae porosae on notogaster. Body and legs covered by cerotegument with or without microtubercles. Cuticle smooth, foveate or reticulate. Prodorsal apodemata generally present. le dorsal, dorso-lateral or lateral, anterior or almost at ro level; ro ventral; in reduced, between bothridia; bothridium dorsal to dorso-lateral, leaned or not against notogaster; ss flagellate, rodlike, fusiform, club-shaped or leaf-shaped, with distal spinules. Notogaster centro-dorsal setae absent; with six pairs of postero-lateral notogastral setae (ps1, ps2, ps 3, h1, r2, r3), or five (r3 absent), or four pairs (r3, h1 absent). Three pairs of dorsal lyrifissures (ia, im, ip) and two pairs of lateral lyrifissures (ips, ih). Notogaster ovate or circular, flat (convex in Licnobelba). Notogastral tectum between bng and lambda lines (except Licnobelba). Apo I complete; all other apodemata incomplete, with or without transversal apodematic bonds. Epimeral chaetotaxy $3: 1: 3: 3$ or with epimeral neotrichy; epimeral setae of equal size, or with the epimere I first row setae larger than the others when neotrichy is present. Genital aperture square to almost circular; anal aperture pyriform, cylindrical or circular; genital and anal apertures contiguous joint or not joint. Genitoanal chaetotaxy 8 or 7 (or 6$)-1-2$ to $8-3$; genital setae on a sole longitudinal row or on more than one row, or yet set on arc; ag lateral to posterior to genitalia. Pedotecta I, II absent; pedotectal tooth p present; lateral carenae present; acetabula I, II integument and cotyloid forming a bunt structure. Leg articulations on proximal - sockets, i. e., sockets on proximal ends of tarsi, tibiae and genua; Tr and Fe - Tr articulations of legs I, II outside acetabula; femofemora proximal portion after trochantera articulation almost, straight; femoral and trochanteral tracheae present; with tree small, median or large claws, the middle claw generally larger than the laterals tarsi pedicels present, narrow; Ts I famulus enclosed or free; p Ts I an euphatidium; omega 1 Ts 1 paraxial, larger than omega 2, both set on a distal apophysis; tibial apophysis I short, median or large, bearing two solenidia; fil Tb I long, antixial; fi2 short, paraxial, femora not bulbous; Ts II with two close solenidia; pl'Ts III absent or present; pl' Ts IV absent; (it) Ts IV absent or present. Leg chaetotaxy: Ts. $19(2)-17(2)-16($ or 15$)-15$ (or 12); Tb. $4(2)-5(1)-4(1)-4(1)$; Ge. $4(1)-4(1)$ or $3(1)-3(1)$ or $2(1)-3$ or $2 ; \mathrm{Fe} .8-8-5-5$ or $5-$ $5-3-2 ; \operatorname{Tr} .1-1-4-3$ or $1-1-2-1$.

Recognised families - Plateremaeidae Tragardh, (PASCHOAL 1979, 1987a); Pheroliodidae Paschoal, (PASCHOAL 1987b); Nooliodidae Paschoal, (PASCHOAL, 1989d); Hammeriellidae Paschoal, (PASCHOAL, 1989a); Lyrifissellidae Paschoal, (PASCHOAL, 1989e); Pedrocortesellidae Paschoal, (PASCHOAL, 1987c); Licnobelbidae Grandjean, (PASCHOAL,1987d). 


\section{Key to superfamilies, families and genera}

1 - Pedotecta I, II auriculiform; pedotectal tooth $\mathbf{p}$ absent; acetabula I, II integument and cotyloid forming a pointed structure; leg articulations not on proximal sockets or with sockets only at the adult stage; $\operatorname{Tr}$ and $\mathrm{Fe}$ - Tr articulation of legs I, II inside acetabula; tarsi fusiform, pedicels absent; Ts II with sixteen tactile setae; fil Ts I associated with a tactile seta; without femoral tracheae . . . . . . . . . . . . .

GYMNODAMAEOIDEA ...........

- Pedotecta I, II absent; pedotectal tooth p present; acetabula I, II integument and cotyloid forming a blunt structure; leg articulations on proximal sockets; $\mathrm{Tr}$ and $\mathrm{Fe}-\mathrm{Tr}$ articulations of legs I, II outside acetabula; tarsi not fusiform with pedicels; Ts II with seventeen tactile setae; fil Ts I not associated with a tactile seta; femoral tracheae present . . . . . . PLATEREMAEOIDEA . . . . . 13

2 - Adults with no exuviae; body and legs covered by a thin cerotegument layer with microtubercles; ss with spinules; notogaster flat; ag lateral or postero-lateral to genitalia leg setae not on tubercles; fi2 $\mathrm{Tb}$ I short ...

- Adults with exuviae; body and legs covered by a thick cerotegument layer without microtubercles; ss flagellate, with out spinules; notogaster convex; ag posterior to genitalia; leg setae on tubercles; fi2 $\mathrm{Tb}$ I median Aleurodamaeidae Paschoal \& Johnston . . . . . . . . . .

Aleurodamaeus Grandjean

3 - le dorsal, posterior to ro; ss filiform, long; with three pairs of anal setae; Ts II with just one solenidium omega, of large size; notogaster convex anteriorly; ft' Ts III, IV present . . . . I Idiodamaeidae Paschoal . . . . .

Idiodamaeus Paschoal

- le anterior or at ro level; ss clavate; two pairs of anal setae; Ts II with two equally developed omega solenidia; notogaster flat; ft' Ts III , IV absent . . . . . . . Gymnodamaeidae Grandjean . . . . . . . 4

4 - Body larger than $500 \mu$; apo in present; in on strong tubercle set on apo in, anterior to bothridia . . . . . . . . . . . . 5

- Body smaller than $500 \mu$; apo in absent; in on small tubercle, between bothridia or a little anterior to it . . . . . . . . . . . 10

5 - Cerotegument piled on dorsum body; one sole pairs of genital setae close to genitalia inner margin; acetabula I, II integument and cotyloid not sharp pointed; pv' Ts I posterior to pv"; d Ge I, II close to distal margin; $\mathbf{d}$ Tb II on distal half; $\mathbf{d}$ Ge IV medial

Plesiodamaeus Grandjean

- Cerotegument not piled; all genital setae close to inner margin; acetabula I, II integument and cotyloid sharp pointed; pv'Ts I anterior to or at the level of pv"; $\mathbf{d}$ Ge I, II proximal or medial; $\mathbf{d}$ Tb II proximal; $\mathrm{d}$ Ge IV close to the proximal or distal boundaries . . . . . . . 6

$6-\mathrm{Ts}-\mathrm{Tb}, \mathrm{Tb}-\mathrm{Ge}, \mathrm{Ge}-\mathrm{Fe}$ articulations not on sockets ..... 7

- $\mathrm{Ts}-\mathrm{Tb}, \mathrm{Tb}-\mathrm{Ge}, \mathrm{Ge}-\mathrm{Fe}$ articulations on sockets ....... 9 
7 - Two setae on Fe IV; notogaster with anterior tubercles; h1, ps 1, ps2 setae bases on prominent folds of distal body margin . . . . . . . . . . .

Pleodamaeus Paschoal

- Three setae on Fe IV; notogaster with no anterior tubercles; h1, ps1, ps 2 setae bases not on folds .................. 8

8 - Genitalia inner margins dentate; genital and anal apertures contiguous, the openings not joint; $3 \mathrm{c}$ on lateral tubercles; epimeral furrow boundaries tuberculate ........... Odontodamaeus Paschoal

- Genitalia inner margins smooth; genital and anal apertures contiguous, the openings completely joint; $3 \mathrm{c}$ not on tubercles; epimeral furrow boundaries smooth . . . . . . . . . . . . . Gymnodamaeus Kulczynski

9 - le dorso-lateral, anterior to ro, close to it; central notogaster with no ornaments; hl subterminal; la on epimere I; genital and anal apertures very close together; acetabulum IV near acetabulum III; pedotectal apophysis absent ............... Adrodamaeus Paschoal

- le lateral, almost at ro level; central notogaster ornamented; $\mathbf{1}$ terminal; 1a on epimere II; genital and anal apertures contiguous, the contours no longer seen at the contact area (ano-genital bridge present); acetabulum IV not too close to acatebulum III; pedotectal apophysis present.

Arthrodamaeus Grandjean

10 - Six pairs of genital setae; microtubercles large; ip very long.

Joshuella Wallwork

- Seven pairs of genital setae; microtubercles small; ip not too long

11 - Three setae on Fe IV; apo bo present; in anterior to bothridia; la on epimere I; two pairs of adanal setae; v' Ge II anterior to the lateral

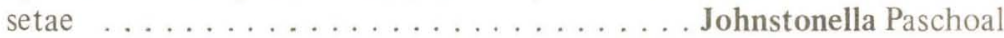

- Two setae on Fe IV; apo bo absent; in between bothridia; la on epimere I or II; two or three pairs of adanal setae; v' Ge II at the level or posterior to the lateral setae ... . . . . . . . . . . . 12

12 - la on epimere I; two pairs of adanal setae; apo ro an incomplete bar; le dorso-lateral, projecting slightly beyond rostrum tip; ss with large head; ip long; $r 2$ present; h1 tubercles not coalescent; fi Tb III, IV close to

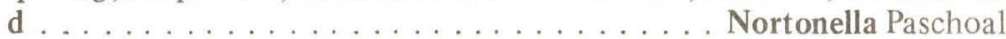

- la on epimere II; three pairs of adanal setae; apo ro a complete bar;le lateral, well projected beyond rostrum - tip; ss with small head; ip short; r2 absent; hl tubercles coalescent; fi Tb III, IV away from d . . . .

Jacotella Banks

13 - Body covered by a thick layer of cerotegument without microtubercles; ss flagellate, rodlike or clavate; le almost at ro level; apo I with a long bar turned backward; with epimeral neotrichy; epimere I setae larger than the others; genital and anal apertures almost circular; seven pairs of genital setae on more than one longitudinal row; tarsi pedicels long; anal plate with four to eight pairs of setae; Fe. chaetotaxy $8-8-5-$ 5 ; Tr. chaetotaxy $1-1-4-3 \ldots \ldots$ Plateremaeidae Tragardh ............................... 14 
- Body covered by a thin layer of cerstegument with or without microtubercles; ss fusiform, clavate or leaf-shaped; le anterior to ro; apo I long bar absent; without epimeral neotrichy; epimeral setae of equal size; genitalia square, anal aperture pyriform generally; seven, six or five pairs of genital setae on a sole longitudinal row, or with eight pairs on more than one row; tarsi pedicels short; anal plate with three or two pairs os setae; Fe. $5-5-3-2$; Tr. $1-1-2-1 \ldots \ldots$

14 - Cuticle smooth; ss flagellate, long; notogaster circular; r3 dorsal, close to the margin; seven pairs of anal setae; pedotectal tooth a present; Ts I famulus free; pl" Ts III, IV absent . . . . . . . . . . . . . .

Plateremaeus Berlese

- Cuticle foveate or smooth; ss flagellate, rodlike, or clavate; notogaster ovate or circular; r3 away from the margin; six, five or four pairs of anal setae; pedotectal tooth a absent; Ts I famulus generally enclosed; pl" Ts III, IV present or absent . . . . . . . . . . . . . 15

15 - ss flagellate or rodlike; four or six pairs of anal setae; leg segments with crests . . . . . . . . . . . . . . . . . . . . 16

- ss clavate; five or six pairs of anal setae; leg segments without crests

16 - ss rodlike, long, straight; notogaster circular; hl away from the homologous seta; anal and genital apertures apart one from the other; four pairs of anal setae; femoral crests well developed

Lopheremaeus Paschoal

- ss flagellate, curved,notogaster ovate; hl close to the homologous seta; anal and genital apertures contiguous; six pairs of anal setae; crests

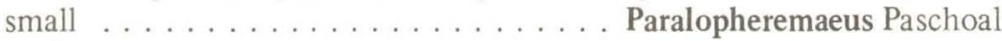

17 - Cuticle smooth; ss club well developed; hl, r2 at notogastral margin; anal and genital apertures partially joint, with on ornaments; six pairs

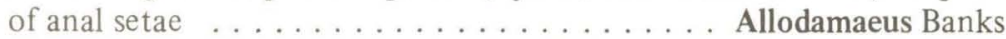

- Cuticle foveate, ss club small; hl, r2 subterminal; apertures no too close, with ornaments; five pairs of anal setae ... . . Calipteremaeus Paschoal

18 - Three pairs of anal setae; five pairs of notogastral setae; without a median transversal furrow on prodorsum . . . . . . . . . . . . . . . 19

- Two pairs of anal setae; six, five or four pairs of notogastral setae; with or without a mediam transversal furrow on prodorsum . . . . . . .

19 - Cuticle foveate or reticulate; ss clavate the club globose, black; seven pairs of genital setae; tarsi pedicels extremely short, with three strong claws; pl'Ts II, III present; (it) Ts IV present . . . . . . . . . . . . . . . Hammeriellidae Paschoal . . . . . . . . . . . . . . . . . . 20

- Cuticle foveate, reticulate or smooth;ss fusiform, clavate or leaf-shaped; eight, seven or six pairs of genital setae; tarsi pedicels short, with three median to small claws; pl'Ts II, III absent; (it) Ts IV absent . . . . . 22

20 - le lateral; bothridium away from notogaster; ss totally enclosed in bothridium; ps2, ps3 anterior to r2; ip small; tibial I apophysis long; leg 
segments very long . . . . . . . . . . . Novazelandiella Paschoal

- le dorsal to dorso-lateral; bothridium close to notogaster; ss free distally; ps2, ps3 posterior to $\mathrm{r} 2$; ip long; tibial I apophysis short; leg segments normal ....................... 21

21 - Adults with exuviae; le dorsal; ss distally globose; $\mathbf{r} 2$ dorsal; notogaster circular; without femoral crests; (it), (tc) on strong apophyses; $\mathrm{pl}^{\prime}$ Ts IV absent . . . . . . . . . . . . . Hammeriella Paschoal

- Adults without exuviae; le dorso-lateral; ss slightly clavate; r2 lateral; notogaster ovate; with femoral crests; (it), (tc) not on apophyses; pl'Ts IV present . . . . . . . . . . . . . . Andesperuviella Paschoal

22 - Cuticle smooth; ss fusiform; notogaster rounded; anal aperture rectangular; eight pairs of genital setae; three median size claws, the laterals quite slender . . . . . . . Nooliodidae Paschoal

Nooliodes Paschoal

- Cuticle foveate or reticulate; ss leaf-shaped or clavate; notogaster ovate; anal aperture pyriform; seven or six pairs of genital setae; three small claws, the medial the strongest ...... Pheroliodidae Paschoal .

23 - Prodorsal apodemata absent or reduced; ss leaf-shaped; hl away from the homologous seta; six pairs of genital setae, on arc; with femoral crests . . . . . . . . . . . . . . . Licnoliodes Grandjean

- Prodorsal apodemata present, well developed; ss clavate; hl close to the homologous seta; seven pairs of genital setae, on a sole longitudinal row; with or without femoral crests . . . . . . . . . . . . 24

24 - ps2, ps 3 close together away from ps $1 ; \mathrm{ps} 3$ anterior to $\mathrm{r} 2$; h1 not too close to the homologous seta; $\mathrm{r} 2$ at notogastral margin (it), (tc), (u) on apophyses; Ts I famulus free

Octoliodes Paschoal

- ps2, ps3 close to ps1; ps3 posterior to $\mathrm{r} 2$ generally; hl close to its homologous seta; $\mathbf{r} 2$ dorsal, not at notogastral margin; (it), (tc), (u) not on apophyses; Ts I famulus enclosed . . . . . . . . . 25

25 - Adults with exuviae; le lateral; bothridium not coiled; notogaster without a posterior deep furrow; three small claws; without femoral crests; (it) Ts IV absent . . . . . . . . . . . Pheroliodes Grandjean

- Adults without exuviae; le dorsal; bothridium coiled; notogaster with a posterior deep furrow; three median size claws; with femoral crests; (it) Ts IV present . . . . . . . . . . . . Lopholiodes Paschoal

26 - With a median transversal furrow on prodorsum; le close to ro; ss clavate; six or five pairs of notogastral setae; ps2, ps3 dorso-lateral to dorsal; seven pairs of genital setae, on a sole longitudinal row or on a semicircle; with true tarsi pedicels; notogaster flat; with notogastral tectum ....................... 27

- Without a median transversal furrow on prodorsum; le away from ro; ss flat, leaf-shaped; five or four pairs of notogastral setae; ps2, ps3 ventral, posterior to $\mathrm{r} 2$; six or five pairs of genital setae, on arc; without true tarsi pedicels; notogaster convex or flat; without notogastral tectum 
27 - Five pairs of notogastral setae; notogaster distal margin salient; hl close to the homologous seta; notogaster rounded; genital and anal apertures completely joint; ag posterior to genitalia; three strong claws; pl'Ts II present; ft'Ts IV present . . . . . . . Lyrifissellidae Paschoal . . . . . . . . . . . . . . . . . . Lyrifissella Paschoal

- Six or five pairs of notogastral setae; notogastral distal margin invaginated; hl away from the homologous seta; notogaster ovate; genital and anal apertures partially joint; ag lateral to genitalia; three small claws, the laterals quite slender; pl' Ts II absent; ft' Ts IV absent Pedrocortesellidae Paschoal . . . . . . . . . . 28

28 - le dorsal; r3 absent; r2 close to ip; h1, ps 2, ps3 away from notogastral margin; genital setae on semicircle; (tc), (it) not on apophyses . . . . . . Pedrocortesella Hammer - le lateral; r3 present; r2 away from ip; h1, ps2, ps3 well at the margin; genital setae on a sole longitudinal row; (tc), (it) on apophyses . . . . . .

29 - Adults without exuviae; cuticle reticulate or smooth; bothridium with two sharp saliences; five pairs of notogastral setae; hl away from the homologous seta; lyrifissures large; warts absent; five pairs of genital setae; famulus free on Ts I . . . . Licnodamaeidae Grandjean . . . . . .

Licnodamaeus Grandjean

- Adults with exuviae; cuticle smooth, shiny; bothridium with just one sharp salience; five or four pairs of notogastral setae; hl very close to the homologous seta; lyrifissures small; warts present; six pairs of genital setae; famulus enclosed on Ts I . . . . . . . . . . Licnobelbidae Grandjean .................. Licnobelba Grandjean

\section{REFERENCES}

BALOGH, J. 1972. The oribatid genera of the world. Akademiai Kiadó, Budapest, 188 pp.

GRANDJEAN, F. 1954. Observations sur les oribatides (28e . Série). Bull, Mus, Hist. Nat. Paris, 2e. Série 26(2): 204-211.

GRANDJEAN, F. 1965. Nouvelles observations sur les oribates (4 ${ }^{\mathrm{e}}$. Série). Acarologia 7(1): 91-112.

PASCHOAL, A. D. 1975. A revision of the Gymnodamaeidae (Acari, Oribatei): A numerical taxonomic study. Ph. D. Dissertation, the Ohio State University, Columbus, 374 pp.

PASCHOAL, A. D. 1979. Revisão da famılia Plateremaeidae e recaracterização da superfamılia Gymnodamaeoidea (Acari, Oribatei). Tese Livre-Docência, E. S. A. "Luiz de Queiroz", USP, Piracicaba, 373 pp.

PASCHOAL, A. D. 1982a. A revision of the genus Gymnodamaeus (Acari, Oribatei, Gymnodamaeidae), with descriptions of nine new species. Revta bras. Ent. 26(1):113132. 
PASCHOAL, A. D. 1982b. Description of Odontodamaeus, a new genus in the family Gymnodamaeidae (Acari, Oribatei), Revta bras. Ent. 26(2):201-205.

PASCHOAL, A. D. 1982c. Nortonella (Acari, Oribatei), a new genus of Gymnodamaeidae from North America. Revta bras. Ent. 26(2):207-209.

PASCHOAL, A. D. 1983a. A revision of the genus Jacotella (Acari, Oribatei, Gymnodamaeidae) in Noth America, with descriptions of two new species. Revta bras. Ent. 27(2): 127-135.

PASCHOAL, A. D. 1983b. Pleodamaeus, a new genus of Gymnodamaeidae mites (Acari, Oribatei) from North America. Revta bras. Ent. 27(2): 125-127.

PASCHOAL, A. D. 1984a. A revision of the Gymnodamaeidae genus Joshuella (Acari, Oribatei), with description of two new species. Revta bras. Ent. 27(3/4): 197-204.

PASCHOAL, A. D. 1984b. Description of Johnstonella subalpina (Acari, Oribatei), a new species and genus of Gymnodamaeidae from the Neartic Region, Revta bras. Ent. 27 $(3 / 4): 205-210$.

PASCHOAL, A. D. 1984c. Adrodamaeus (Acari, Oribatei, Gymnodamaeidae), a new name for Heterodamaeus Woolley, with a reevaluation of the genus and a description of a new species. Revta bras. Ent. 28(1): 15-21.

PASCHOAL, A. D. 1984d. A revision of the genus Arthrodamaeus (Acari, Oribatei, Gymnodamaeidae), with a description of a new species. Revta bras.Ent. 28(3):2 13-222.

PASCHOAL, A. D. 1984e. Redescription of Plesiodamaeus craterifer (Acari, Oribatei, Gy mnodamaeidae), with a reevaluation of the genus. Revta bras. Ent. 28(4): 369-372.

PASCHOAL, A. D. 1984f. Idiodamaeus (Acari, Oribatei), a new genus of Gymnodamaeidae from South America. Revta bras. Ent. 28(4): 373-377.

PASCHOAL, A. D. 1987a. A revision of the Plateremaeidae (Acari, Oribatei) Revta bras. Zool. 3 (6): 327-356.

PASCHOAL, A. D. 1987b. A revision of the Pheroliodidae fam. n. (Acari, Oribatei) Revta. bras. Zool. 3(6): 357-384.

PASCHOAL, A. D. 1987c. A revision of the Pedrocortesellidae Fam. n. (Acari, Oribatei) Revta. bras. Zool. 3(6): 385-395.

PASCHOAL, A. D. 1987d. A revision of the families Licnodamaeidae and Licnobelbidae (Acari, Oribatei) with a recharacterization of the genera Licnodamaeus and Licnobelba. Revta bras. Zool. 3 (6): 397-403.

PASCHOAL, A. D. 1987e. Idiodamaeidae (Acari, Oribatei): a new family of South American mites, with a restatement of the Gymnodamaeidae. Revta. bras. Zool. 3 (6): 405-407.

PASCHOAL, A. D. 1989a. Description of a new genus - Hammeriella gen. n. from South America and a new family - Hammeriellidae fam. n. (Acari, Oribatei). Revta bras. Zool. 6(1): 17-24.

PASCHOAL, A. D. 1989b. Description of Andesperuviella gen. n. (Acari, Oribatei, Hammeriellidae) from the Peruvian Andes. Revta bras. Zool. 6(1): 25-29.

PASCHOAL, A. D. 1989c. Novazelandiella gen. n. (Acari, Oribatei, Hammeriellidae), a new genus of mites from New Zealand. Revta bras. Zool. 6 (1): 31-36. 
PASCHOAL, A. D. 1989d. Description of Nooliodes gen. n. and Nooliodidae fam.n. (Acari, Oribatei) from Madagascar. Revta bras. Zool. 6(2):179-182.

PASCHOAL, A. D. 1989e. Description of Lyrifissella gen. n. and Lyrifissellidae fam. n. (Acari, Oribatei). Revta bras. Zool. 6(2):183-190.

PASCHOAL, A. D. \& D. E. Johnston. 1982a. A numerical taxonomic revision of the Gymnodamaeidae (Acari, Oribatei). Revta bras. Biol. 42(2): 439-459.

PASCHOAL, A.D. \& D.E.Johnston. 1982b. Revised classification of the Gymnodamaeidae (Acari, Oribatei) with a key to the genera. Revta bras. Biol. 42(2): 461-466.

PASCHOAL, A. D. \& D. E. Johnston. 1984. Aleurodamaeidae (Acari, Oribatei), a new family of Oribatid mites, with a description of Aleurodamaeus hungaricus n. sp. Revta bras. Ent. 29(1): 21-26.

TRAGARDH, I. 1931. Pacific mites: Acarina from the Juan Fernandez Islands. Natural History of Juam Fernandez and Eastern Islands, Uppsala 3(4): 553-628. 